Early Medieval Europe

300-1000 


\section{HISTORY OF EUROPE}

PUBLISHED

Early Medieval Europe 300-1000 (Second edition)

Roger Collins

Sixteenth-Century Europe

Richard Mackenney

Seventeenth-Century Europe 1598-1700

Thomas Munck

Eighteenth-Century Europe 1700-1789

Jeremy Black

FORTHCOMING

Nineteenth-Century Europe 1789-1914

Alan Sked

Twentieth-Century Europe

Richard Vinen 


\section{Early Medieval Europe 300-1000}

Roger Collins

Fellow of the Institute for Advanced Studies

University of Edinburgh

Second Edition

Macmillan Education 
EARLY MEDIEVAL EUROPE 300-1000

ISBN 978-0-333-65808-6 ISBN 978-1-349-27533-5 (eBook)

DOI 10.1007/978-1-349-27533-5

Copyright @ 1991, 1999 by Roger Collins

Softcover reprint of the hardcover 2nd edition 1999

All rights reserved. No part of this book may be used or reproduced in any manner whatsoever without written permission except in the case of brief quotations embodied in critical articles or reviews.

For information, address:

St. Martin's Press, Scholarly and Reference Division, 175 Fifth Avenue, New York, N.Y. 10010

Published in the United States of America

This book is printed on paper suitable for recycling and made from fully managed and sustained forest sources.

ISBN 978-0-312-21885-0 clothbound

ISBN 978-0-312-21886-7 paperback

Library of Congress Cataloging-in-Publication Data

Collins, Roger, 1949-

Early medieval Europe, 300-1000 / Roger Collins. - 2nd ed.

p. cm. - (History of Europe)

Includes bibliographical references and index.

ISBN 978-0-312-21885-0 (cloth). — ISBN 978-0-312-21886-7 (pbk.)

1. Europe-History-476-1492. 2. Europe-History-To 476.

3. Civilization, Medieval. 4. Middle Ages-History. I. Title.

II. Series: History of Europe (St. Martin's Press)

D121.C65 1999

$940.1-\mathrm{dc} 21$ 


\section{Contents}

Chronology of main events, $238-1000 \quad$ viii

Preface to the first edition xix

Preface to the second edition xxii

Introduction xxiii

1 Problem-solving emperors 1

A dynamic age: the Roman Empire, 235-285 1

The reign of Diocletian, 285-305 8

2 The age of Constantine 16

Imperial rivals, 305-312 16

The emperor and his new religion $\quad 17$

Constantine's heirs, 324-350 25

3 Frontier wars and civil wars, 350-395 31

Imperial defence, 350-361 31

Reactionary rebel: the emperor Julian, 361-363 36

Internal conflicts, 363-395 42

4 The battle of Adrianople and the sack of Rome 47

The coming of the Huns 47

The Goths and the Empire, 376-395 51

Stilicho or Honorius? The conflict of two strategies, 395-410 54

5 A divided city: the Christian Church, 300-460 61

Christianity and the Empire 61

The primacy of Peter 68

The rise of monasticism $\quad 75$

6 The disappearance of an army 8

Shrinking the western Empire, 410-454 80

An age of military dictators, 455-480 87

The fall of Rome? 96

7 The new kingdoms $\quad 100$

War lords and kings $\quad 100$

Theoderic and the Ostrogothic kingdom in Italy 105

Clovis 111 
8 The twilight of the West, 518-568 116

Prelude: Constantinople and Rome 116

Justinian I and Africa, 527-533 120

The Italian wars, 535-553 129

9 Constantinople, Persia and the Arabs 135

The Roman Empire and Iran 135

Islam and the Arab conquests 143

10 Decadent and do-nothing kings 153

Visigothic Spain, $c$. 589-711 153

Merovingian Gaul, $c .511-687 \quad 161$

11 The re-creating of Britain 173

Entrepreneurial rulers, 410-597 173

Christian kingdoms, 598-685 179

The Mercian hegemony, 633-874 186

12 The Lombard achievement, c. 540-712 196

The acquisition of Italy, 540-572 196

Dukes and kings, 572-584 201

The kingdom of the Lombards, 584-712 207

13 The sundering of East and West 218

Survivals of cultural unity 218

Iconoclasm: divisions in the East 223

Rome between Constantinople and Francia 228

14 Monks and missionaries 234

Western monasticism: Augustine to Gregory the Great 236

The making of the Irish Church 240

Spreading the word 249

15 Towards a new western Empire, 714-800 262

Charles 'the Hammer' 262

Pippin 'the Short' 271

Charles 'the Great' 278

16 The new Constantine 291

The meaning of Empire $\quad 291$

The machinery of government 298

The ideological programme 301 
17 Frontier societies: Christian Spain, 711-1037 309

The Christians of Al-Andalus $\quad 309$

The kingdoms of northern Spain, $c .718-910 \quad 314$

The kingdom of León and the county of

Castille, 910-1037

18 'The dissension of kings'

Chroniclers in an age of war 333

The reign of Louis the Pious, 814-840 336

Kings and emperors in the West, 840-911 349

19 'The desolation of the pagans' 364

Traders and raiders 364

The Vikings and Francia $\quad 370$

The Vikings and the Anglo-Saxon kingdoms 378

Conversion and expansion $\quad 385$

20 The Ottonian Age $\quad \mathbf{3 9 0}$

The problems of Italy, 875-961 390

Germany: the kingdom and the duchies, 911-962 394

Germany, Rome and Constantinople, 962-983 404

Otto III (983-1002) and the eastwards expansion of Europe

$\begin{array}{ll}\text { Abbreviations } & 423\end{array}$

Notes $\quad 424$

Bibliography $\quad 501$

Index $\quad 514$ 


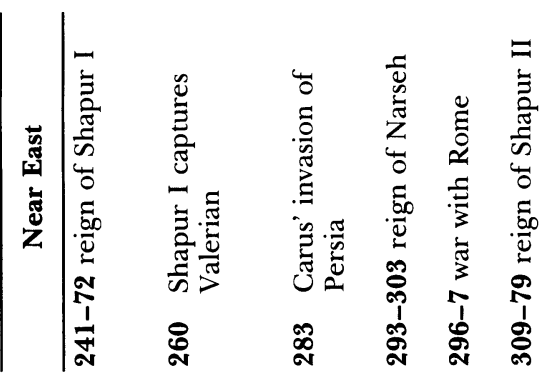

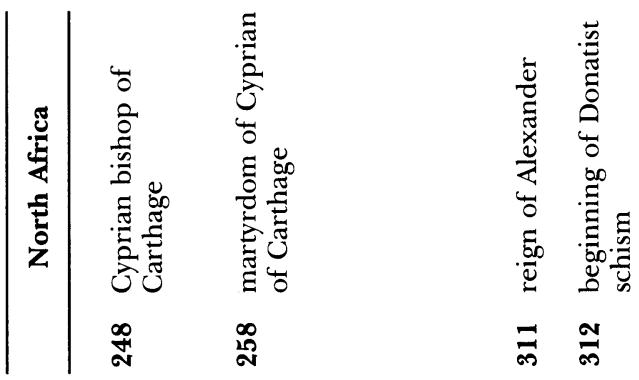

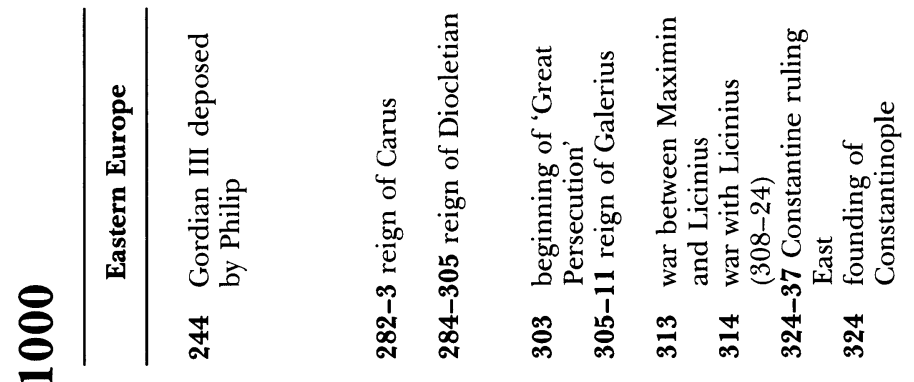

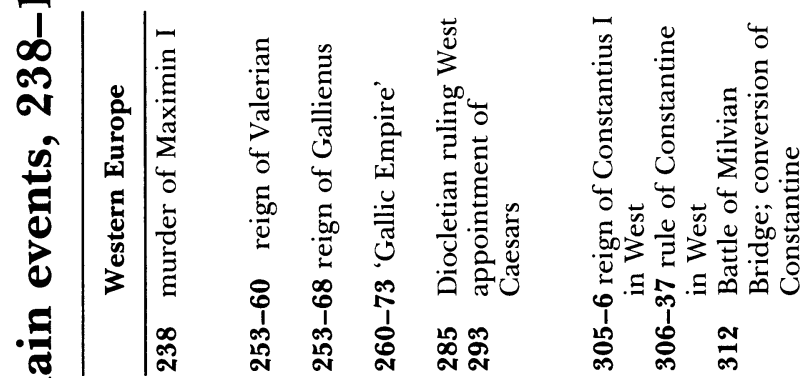

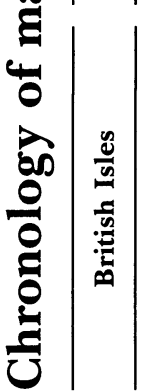

苞

पे

$\frac{60}{20} \cdot \frac{50}{2}$

क ठ ठ

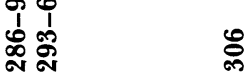




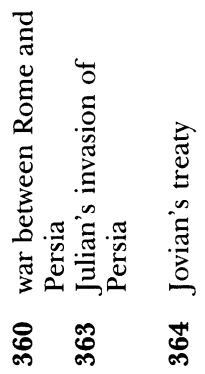

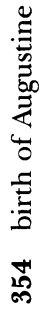

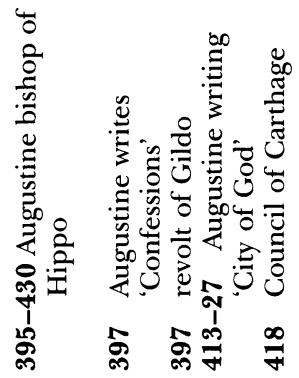

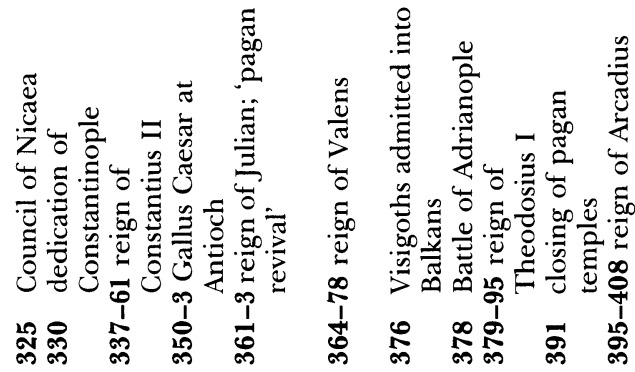

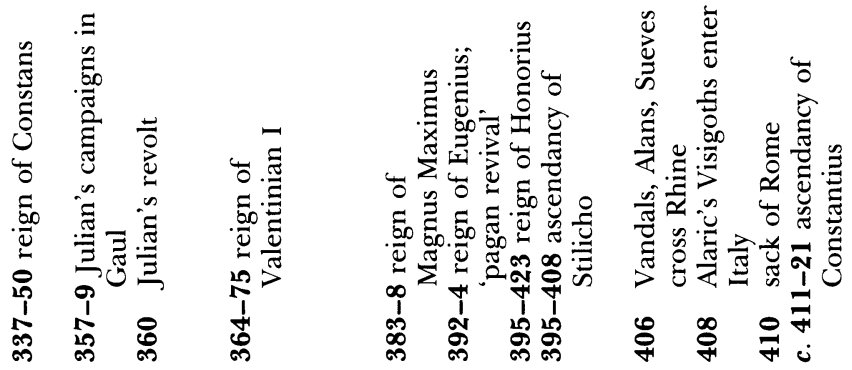
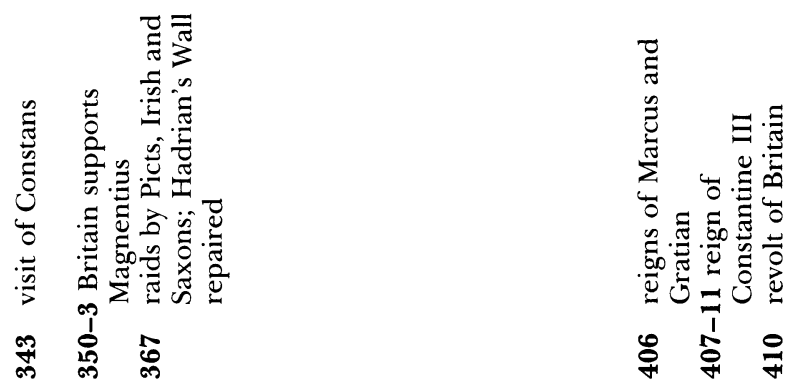


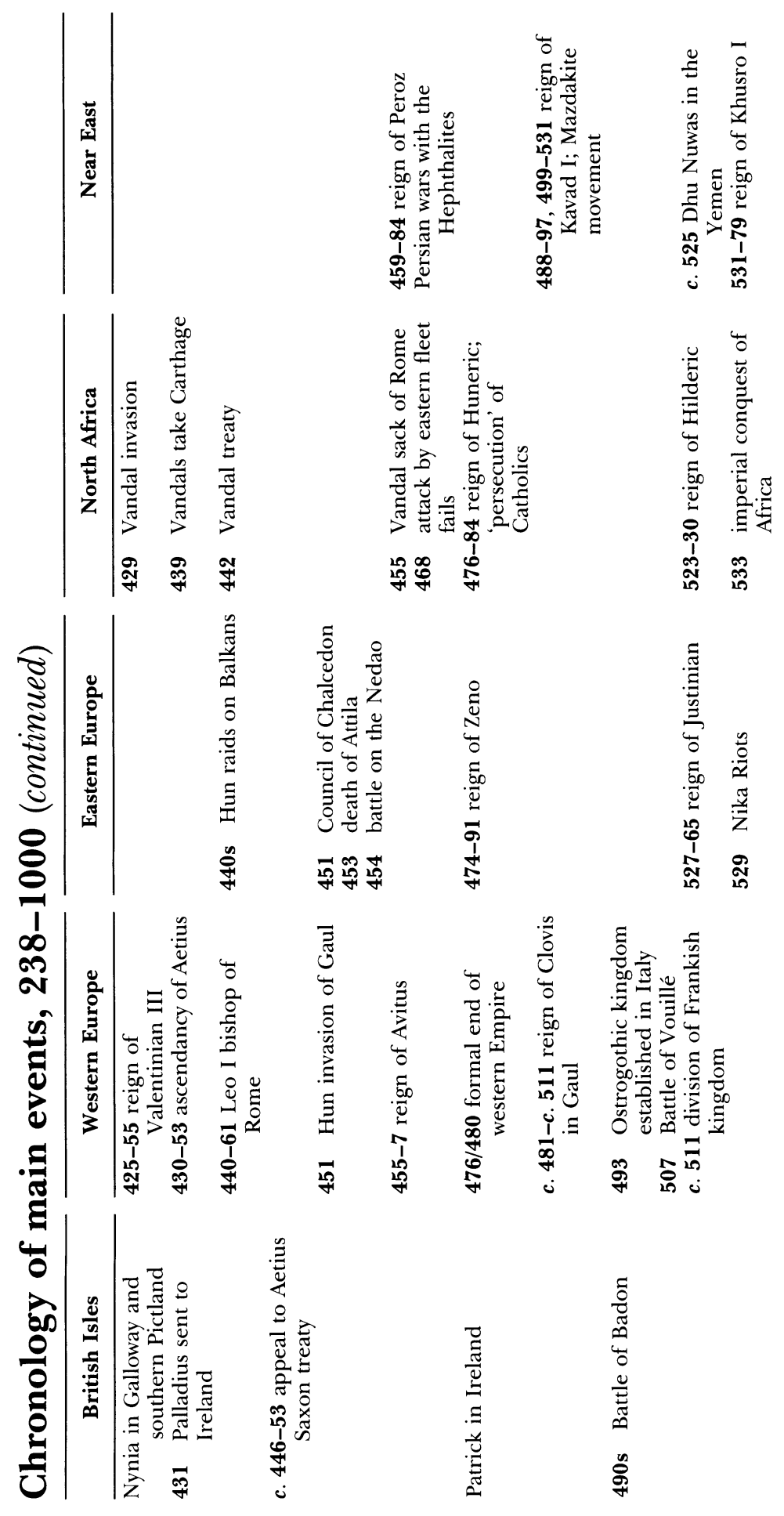




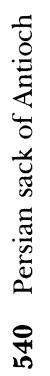
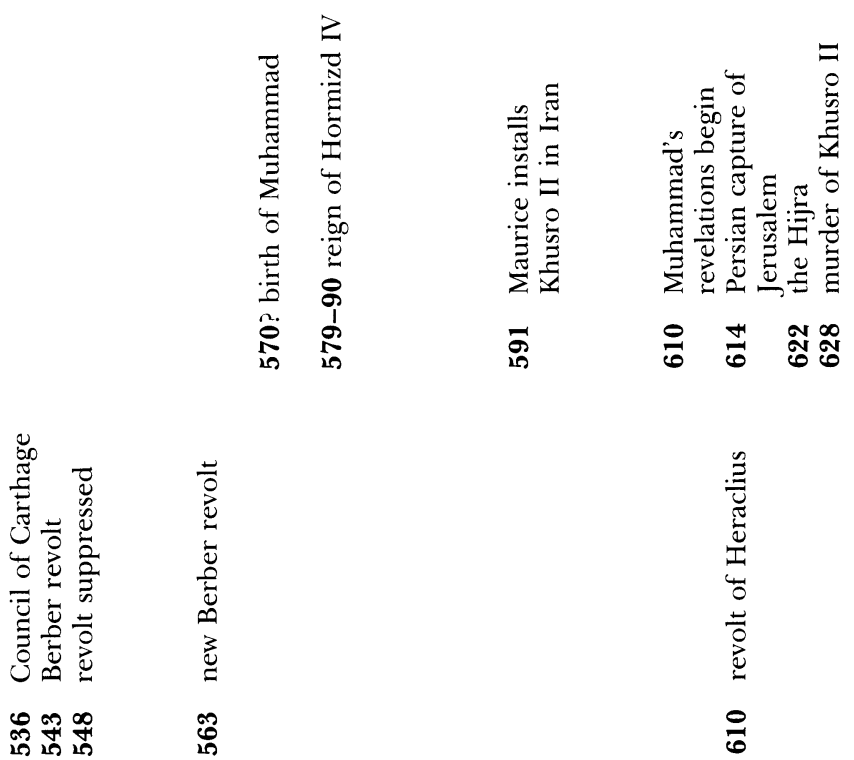

$\stackrel{2}{3}$

ถึ

ถึ

응

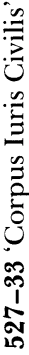
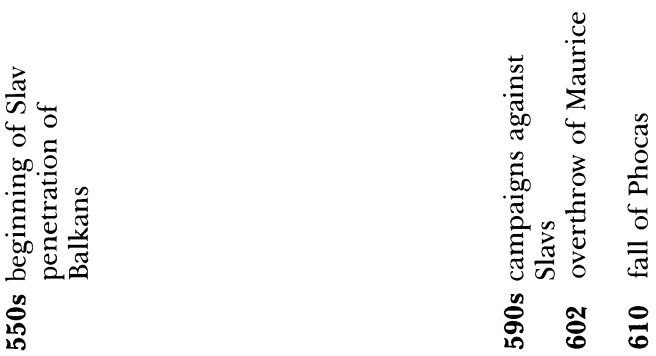

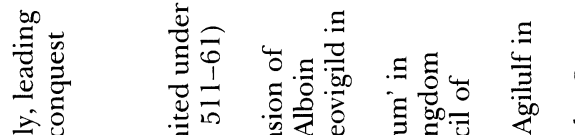

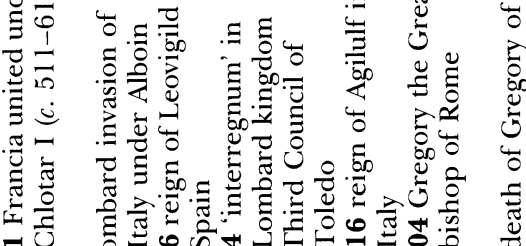

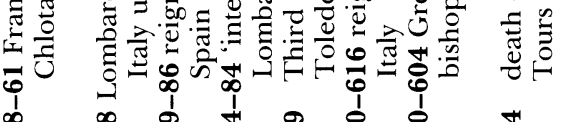

1
10
10

年

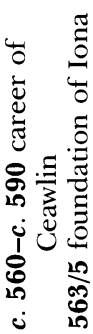

$\Xi$

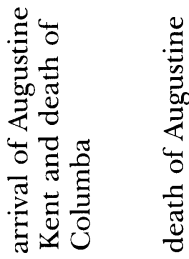

กิ

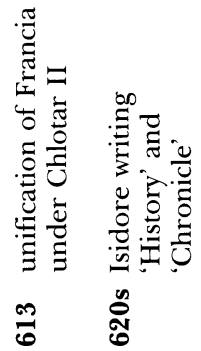

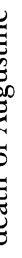

ठั 


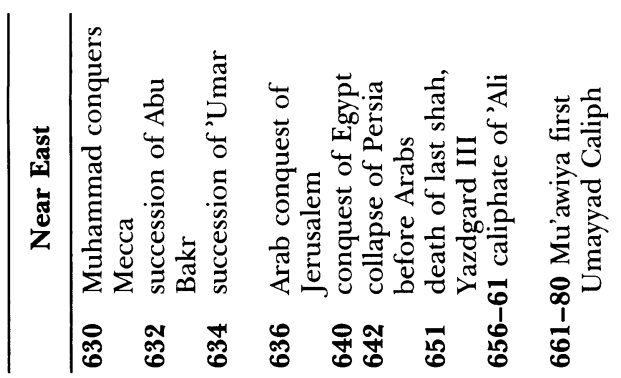

0
3
3
$\vdots$
1
0
0
0
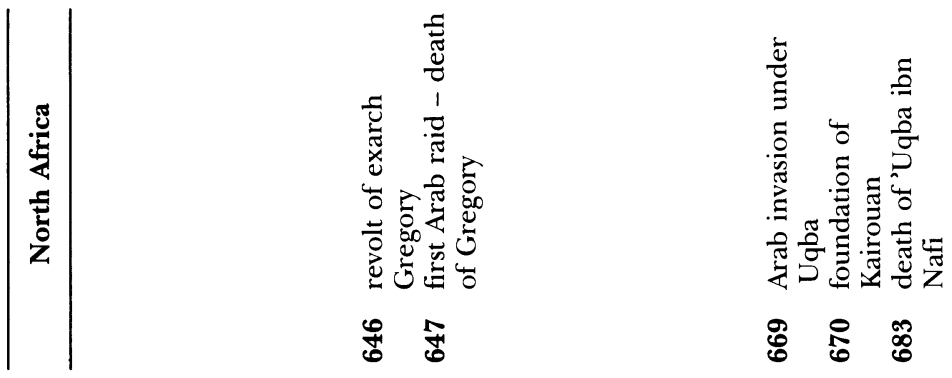

웡 웡

웅 :
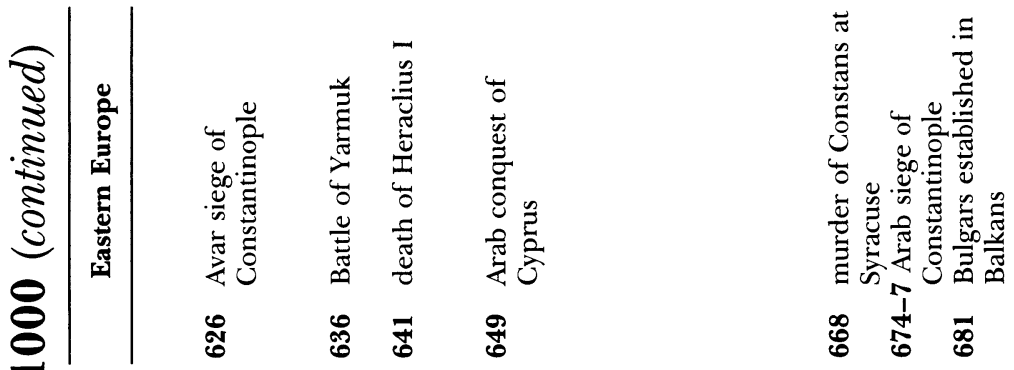

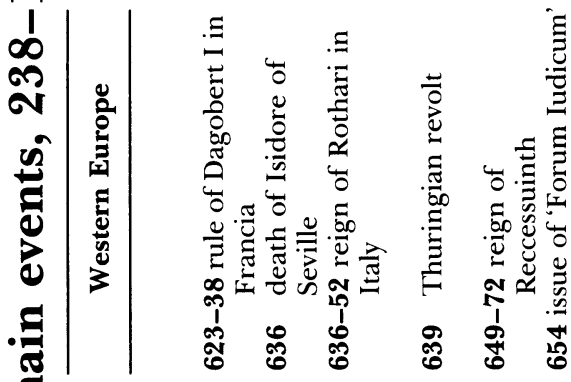

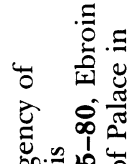

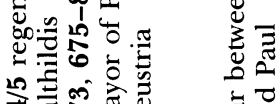

苛

กิ้

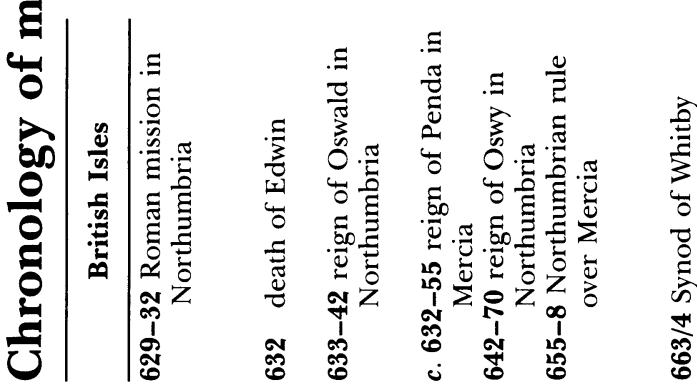

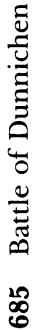




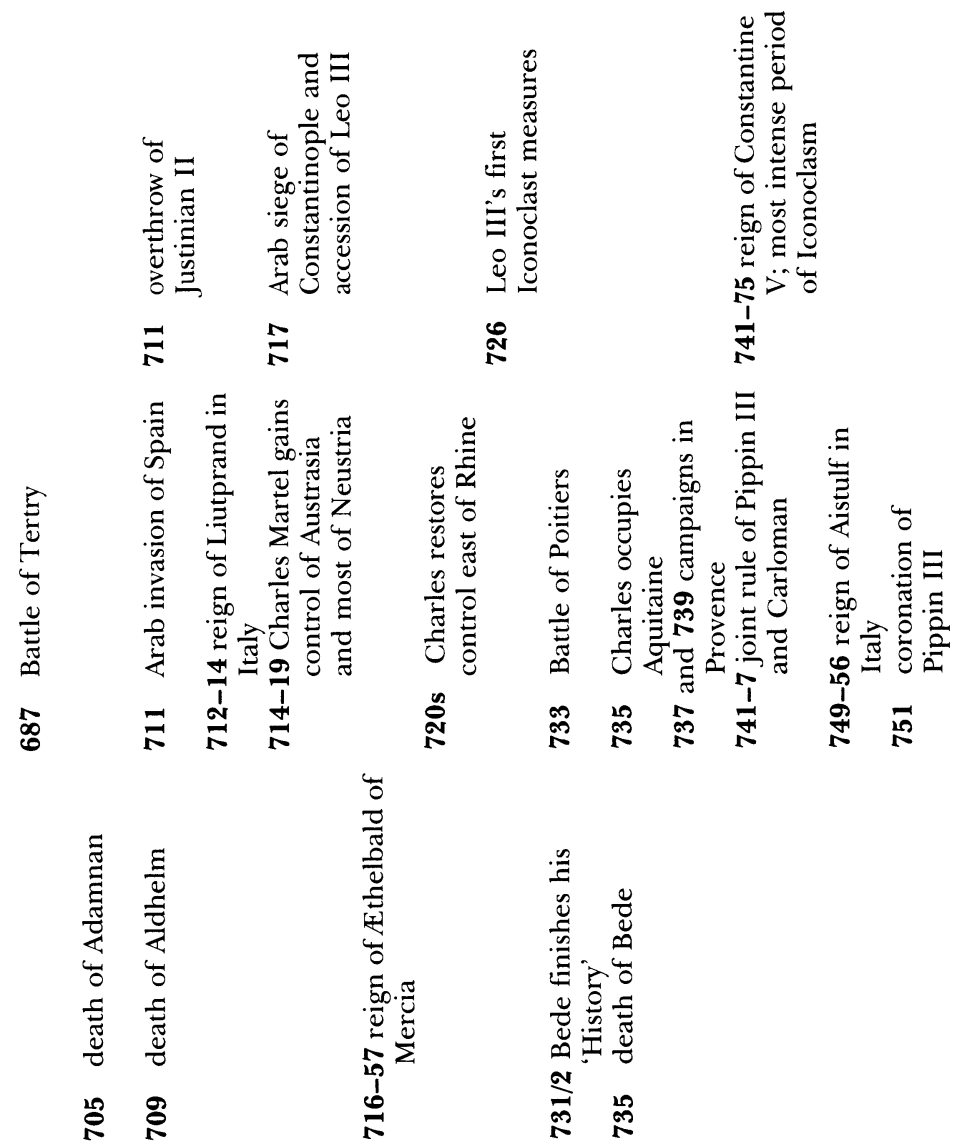



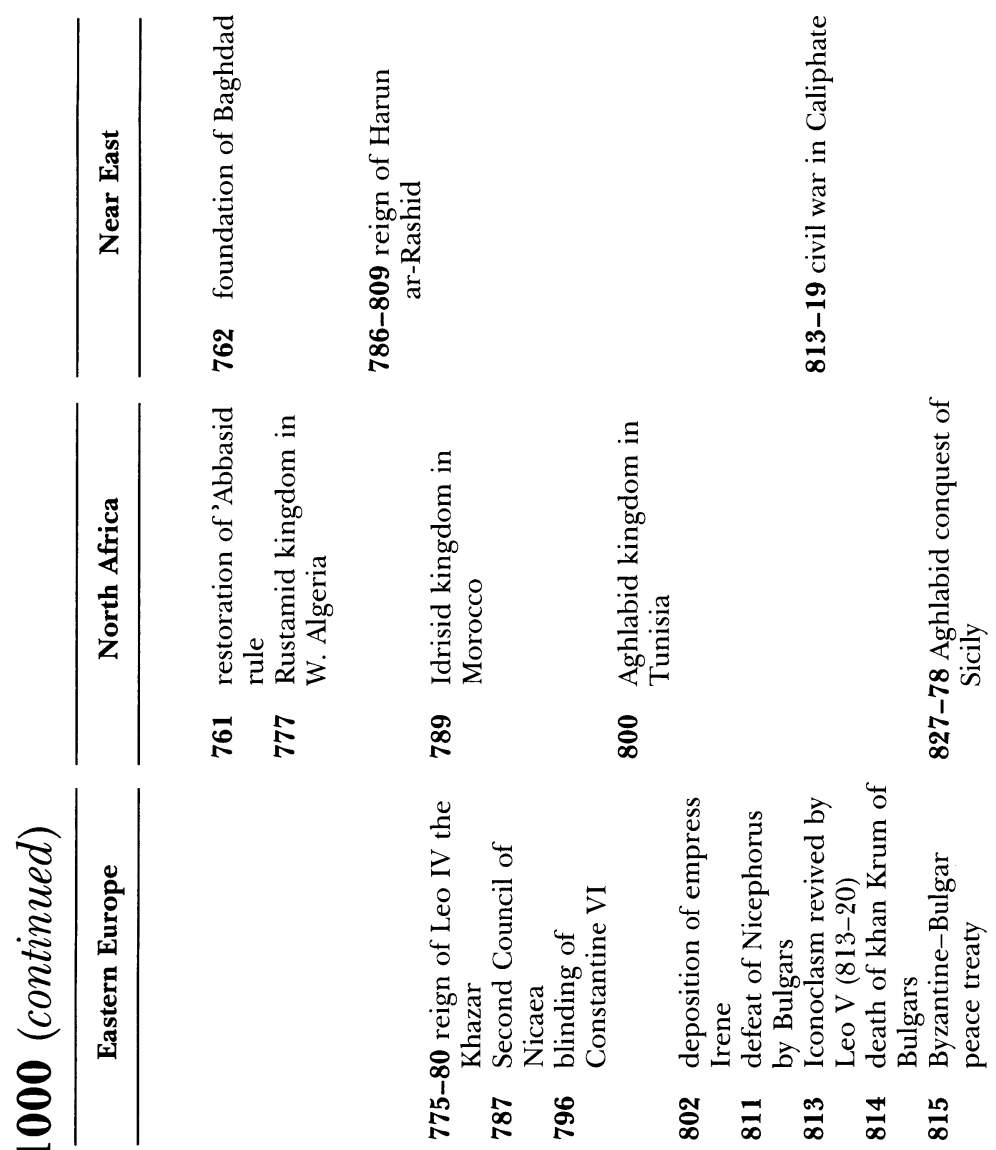

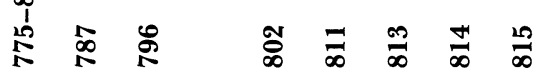
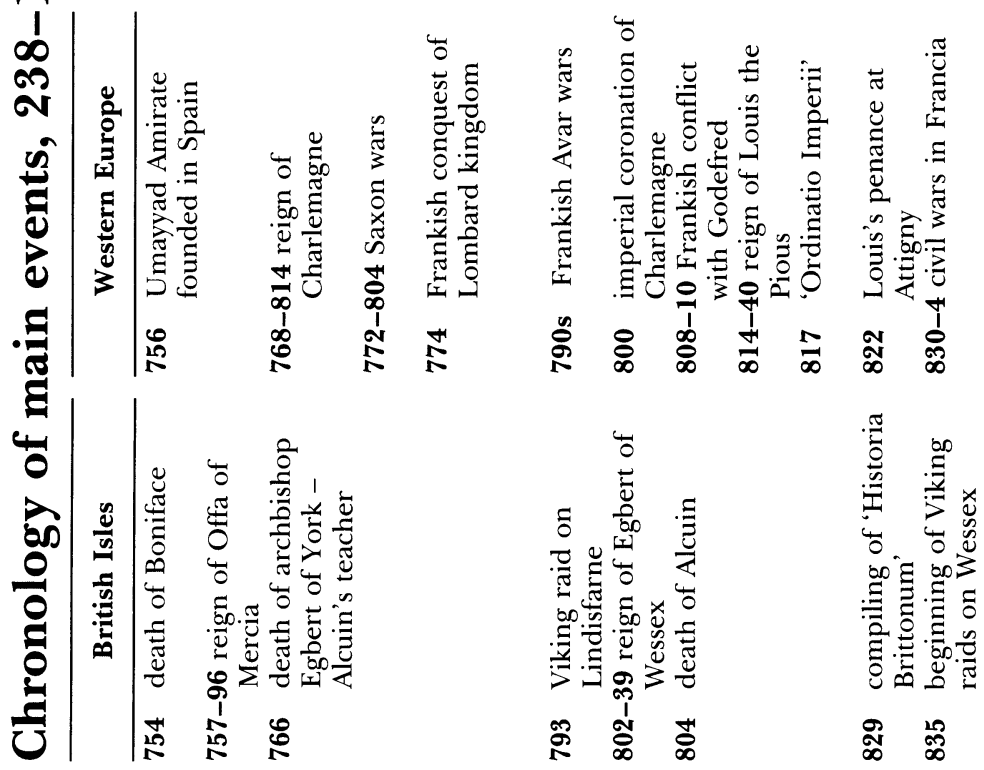


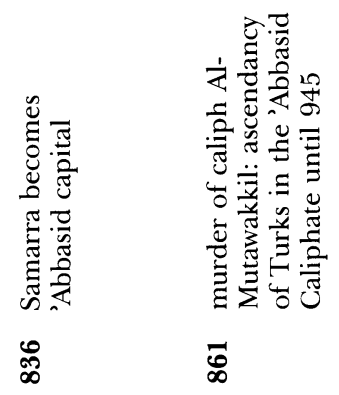

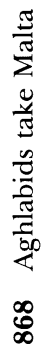

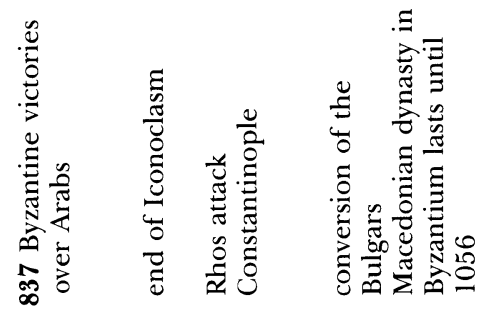

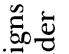

สิ ปี $\stackrel{\infty}{\infty}$ 焉变 ิิ $\Xi$ ๑

ஜ

$\stackrel{\infty}{\infty}$

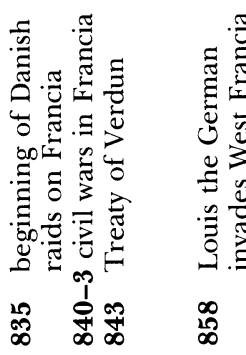
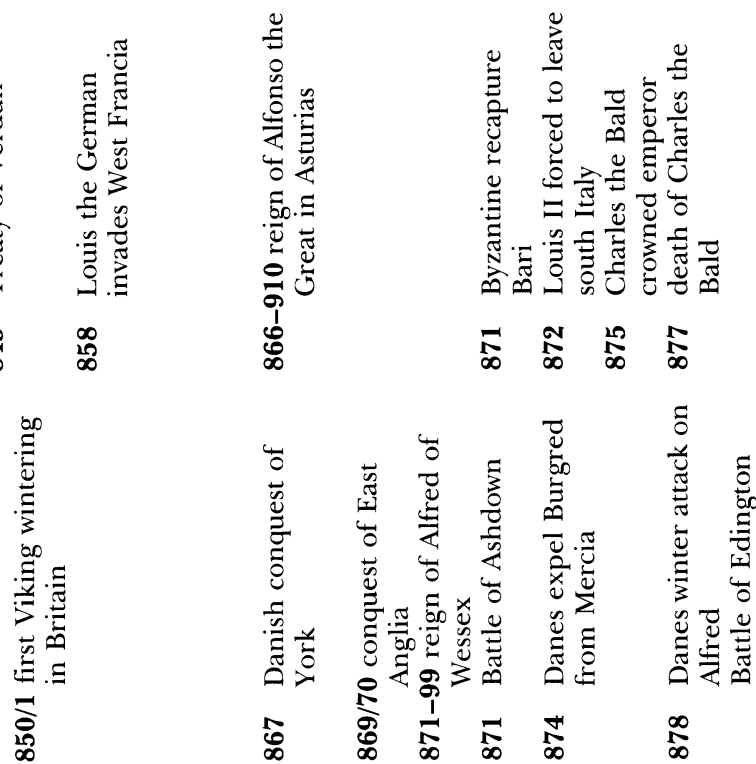

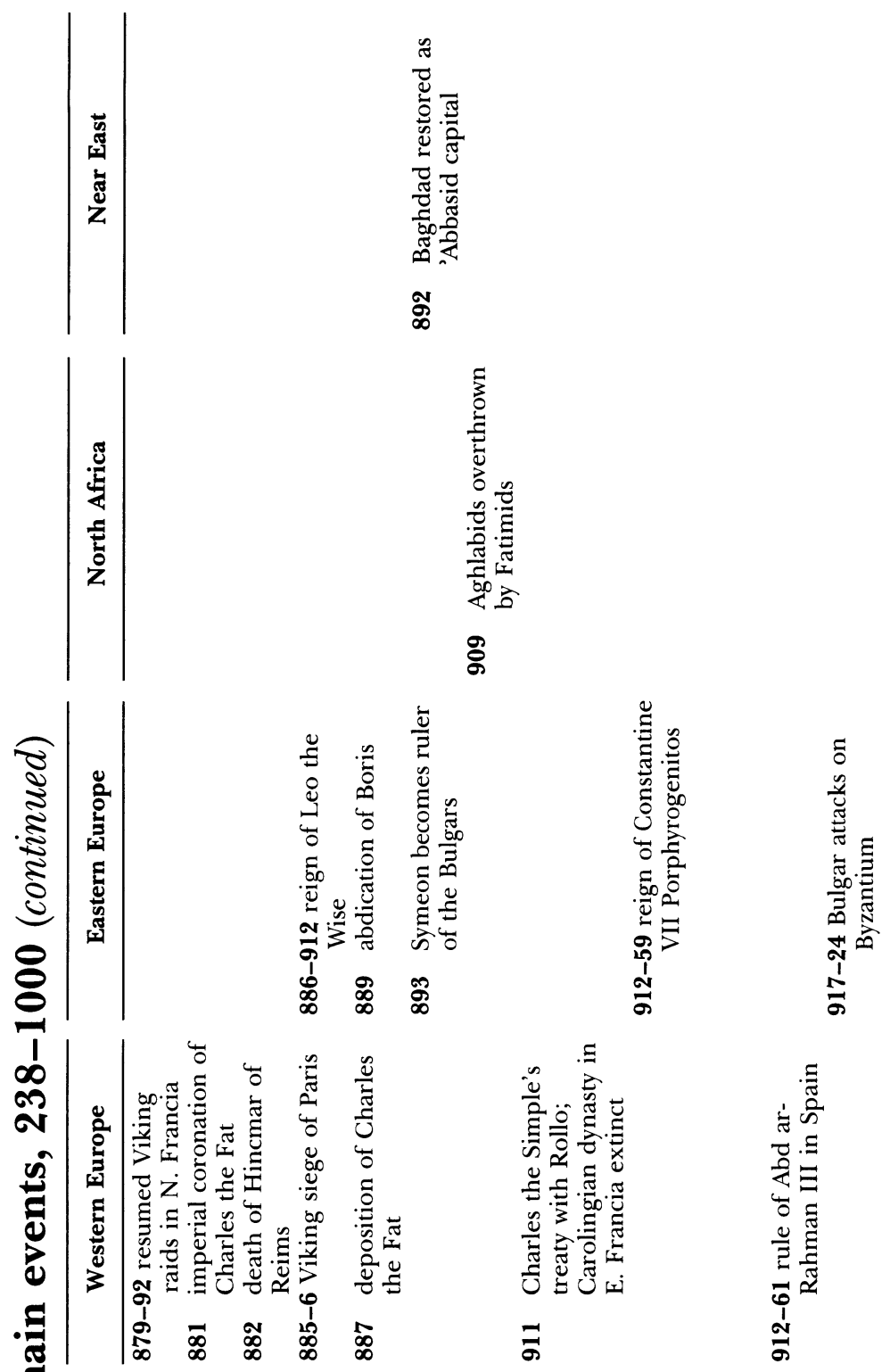

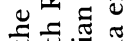

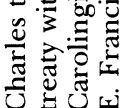

$\bar{\sigma}$

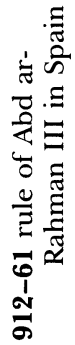

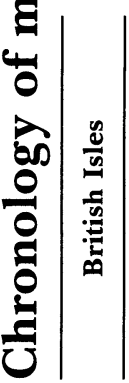
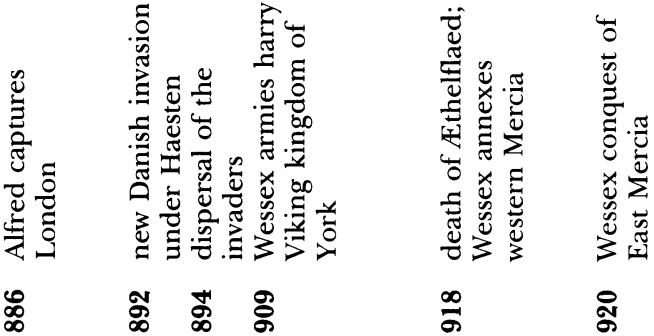


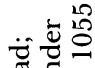

의

하으을

m. ำ

일

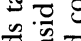

高竞言

恋

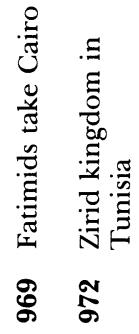

苞

क क त

สิ

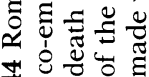

声 ๙ิ

ฟิ

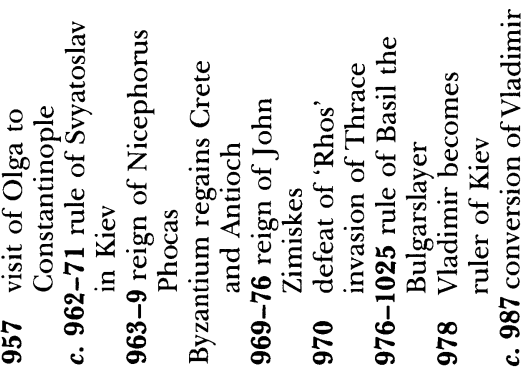

造

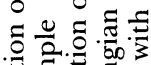

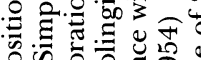

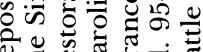

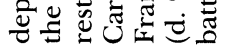

๙ึ. \%

ริ

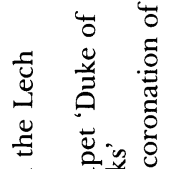

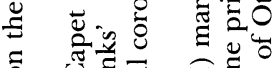

¿

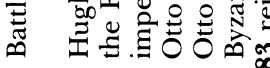

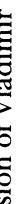

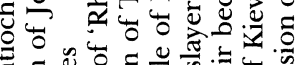

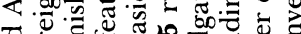

.

î

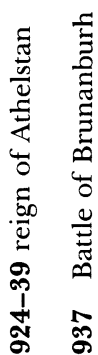

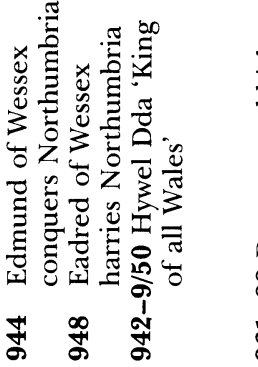

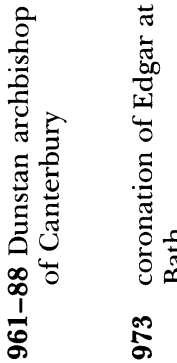

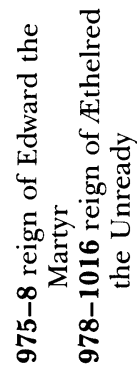



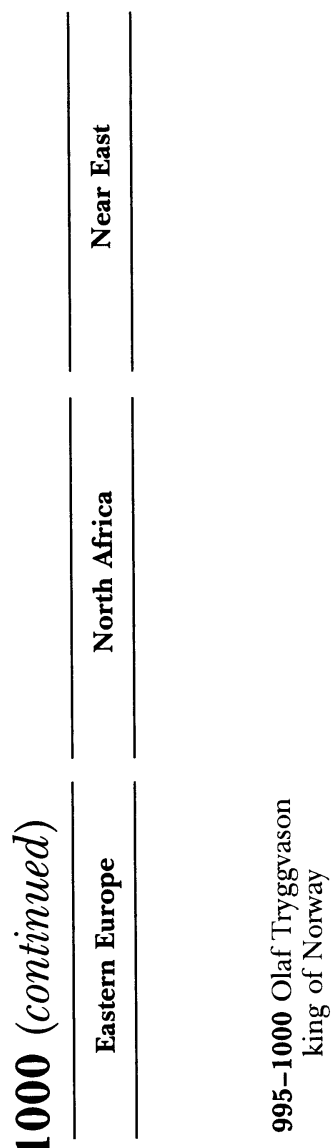

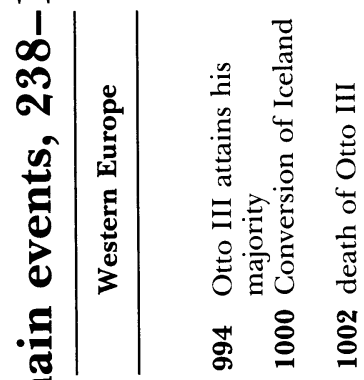

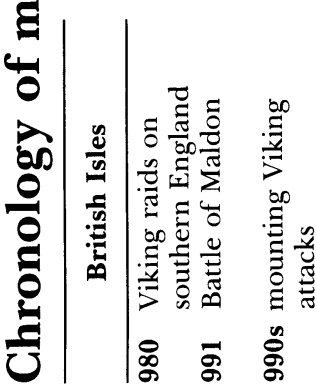




\section{Preface to the first edition}

At an early stage in thinking about the question of its contents it became clear that this was doomed to be a book that nobody could like, or at least that if some of its readers were pleased with some of it, none of them would possibly enjoy all of it. There are too many variables in the topics, themes, events and personalities that have to be considered for inclusion in a work of this (relative!) brevity that has to concern itself with so extended a chronological period. It became increasingly obvious that the real decisions to be made were those concerning what was to be omitted, and for an author temperamentally inclined to squeezing limited and fragmentary evidence as far as it will permit, if not beyond, this has been a particularly hard task.

Wholesale omissions and the reduction of complicated and nuanced arguments to bald assertions are bound to dissatisfy the discerning reader (as much as the author). In consequence, what is attempted here has to be a personal approach that may at times seem wrong headed in its concentration on some subjects to the exclusion of others or its occasional descent into detailed argument that seems out of proportion to the scale of the rest of the book. In that sense I can only fall back on the defence of a great, if idiosyncratic, ninth century bishop, that was recently echoed by a much revered Master: Scripsi quod sensi.

It may seem strange to those unfamiliar with these centuries that such an apology is necessary, and that a period of such apparent remoteness and obscurity should not manage to encompass itself totally in a book of even half the length of this one. Only brief acquaintance, however, will reveal how substantial is the corpus of evidence relating to this time, and how numerous and varied the problems involved in interpreting it. Moreover, the proper understanding of this period involves the historian in moving his gaze on occasion from the western fringes of Iran to Iceland and from Ethiopia and the edge of the Sahara to the steppes of Central Asia. Such breadth of geographical and chronological vision seems to be less necessary - or less demanded in later periods.

In trying to present, even in outline, this series of interrelated developments, it was clearly necessary to push the chronological limits of this book back to an earlier period than those of the beginning of the sixth century, which was where it had first been intended to place them. So much of what was to make up the 
framework of ideas and institutions which shaped subsequent centuries originated in the fourth century that it would have been perverse to start any later than $c .300$, and, indeed, a lack of Late Roman background has often led to mistaken and misleading interpretations of Early Medieval History. In turn, the decision to start with the fourth century prompted at least some preliminary investigation of the third.

Doubtless such a process could be indefinitely prolonged, recessing ever further back in time, but there is a certain rightness about commencing such a study as this in the mid-third century, when so many of the principal ideas and institutions of Antiquity were undergoing transformation. This period, however little studied and poorly documented, represents the first formative stage of the major changes that were to follow, and it is here that this enquiry begins.

Where to end was to some extent predetermined by the structure of the series in which this volume is to appear, but the disintegration of the Frankish successor empire in the late ninth and early tenth centuries again makes for something of a natural break, at least in some aspects of the history of medieval Europe. Extending the survey slightly further than I might have liked, the symbolic date of the year 1000 makes an aesthetically pleasing, if intellectually not entirely satisfying terminal point. To a certain extent, then, this book could have been given such a subtitle as 'From Constantine the Great to Charles the Simple'! In practice, treatment of the tenth century offered here is less full than for some earlier periods, largely because a number of the major themes that have their origin in this, still relatively little studied, time are best considered in the wider context of their development in the eleventh and twelfth centuries.

Other topics that might have merited inclusion have been omitted partly due to personal style and inclination on the part of the author and partly due to the fact that the lack of other general surveys of this period necessitated the provision of a substantial narrative outline of events, taken together with analysis of and comment on the major sources of evidence. In consequence there may be less economic history to be found in this book than some readers might like. This is conditioned on the author's part by a dislike for generalisation based on an insufficiency of evidence, and this is one of several areas for which the Early Middle Ages are poorly equipped in terms of the survival of source material. It is relatively easy to create general models on the basis of limited evidence, but these tend all too often in such circumstances to rest on a priori assumptions as to how societies and their economies should work. Such determinism 
should be resisted. It is also preferable to ask questions of evidence that its particular nature fits it to answer rather than ones that the historian feels he ought to pose.

The first victims of this book - paradoxically, even before it was ever commissioned - were the successive first-year history students in the University of Liverpool, to whom between the years 1974 and 1980 elements of it were expounded in the form of lectures on this period. The most recent guinea pigs to have suffered in its genesis are those former students at the Royal School, Bath, to whom the first edition is dedicated. I am very grateful to them for their enthusiasm in the discussion of a range of issues and topics that are considered in the chapters below. My especial thanks must go to Ian Wood, who read all of the first draft of this book, and whose comments and suggestions on it enabled me to avoid many errors. The greatest debt of all, though, is that to my wife Judith McClure, with whom so much of it has been shared in all of the phases just mentioned and whose role in it is truly omnipresent.

Bath

ROGER COLLINS

September 1990 


\section{Preface to the second edition}

Thanks to that miracle of modern publishing, the text of a book on computer disk, it has been both possible and relatively easy to make changes and corrections throughout. Not only has this meant that errors detected since the first publication of this book, including the most delightful of all, the entirely spurious Anskar's Life of Rimbert, which eluded detection by both author and first readers alike, have been purged, but it has also been possible to make stylistic improvements throughout. In addition, an entirely new chapter on Spain after the Arab Conquest has been included, while the one dealing with the Ottonian Empire has been significantly expanded.

The early medieval centuries have enjoyed a period of remarkable prosperity and growth in terms of the research that has been carried out and the books and articles published on a wide range of subjects relating to them in the course of the 1990s. This flourishing of scholarship has been taken account of as much as has been possible in the preparation of this second edition, and has influenced changes to the text throughout. It will also be seen to be reflected in alterations and additions to both the notes to each chapter and to the general bibliography. In some cases it may be too early to see what constitutes genuine advances in our understanding of this complex period and what may prove to be false starts or misleading trails. Only time will tell.

As in the original edition, the selection of subjects for inclusion and the interpretations offered have ultimately to be matters of personal choice and conviction. While trying to take account of the great wealth of current and past scholarship relating to this period, seven hundred years of the history of Europe, North Africa and parts of the Middle East are not easily to be covered, and fashions in historiography can change rapidly. However, in making revisions I have generally tried to be less judgmental, leaving the reader even greater scope to make her and his decisions as to the merits of the cases argued here.

Edinburgh

ROGER COLLINS

March 1998 


\section{Introduction}

When Gibbon surveyed the centuries of 'decline' in the history of the Roman empire and its Byzantine successor he allowed himself to start with a little mild Utopianism. Of the Antonine period he commented that 'If a man were called upon to fix the period in the history of the world during which the condition of the human race was most happy and prosperous, he would, without hesitation, name that which elapsed from the death of Domitian to the accession of Commodus' (that is AD 96-181). Few might nowadays ask themselves such a question, let alone come up with a response that equates 'the world' exclusively with the Mediterranean and 'the human race' with a small economic and social elite. However, for all of his enthusiasm for second century Rome, some of which was intended as implicit criticism of aspects of his own society of which he disapproved, it was not about this period that Gibbon intended to write.

Periods of tranquillity, social harmony and economic stability do not make very exciting history - even if we now would detect more conflict and change in the second century than was apparent to Gibbon. The turbulent centuries that were to follow pose more interesting historiographical problems, not least because they encompassed the most important developments that would take place in the history of the Near East, the Mediterranean and Western Europe, between the formation of the Roman Empire in the first century $\mathrm{BC}$ and the discovery of the New World in the late fifteenth AD. Even then much of the way that the society and economy of the Americas were to be developed and exploited was directly conditioned by a body of ideas and through the means of institutions that had come into being in the period of the Late Roman Empire.

In general, the centuries covered by this book constitute a period of the greatest significance for the future development, not only of Europe, but also in the longer term of much else of the world. They saw, not least, the establishment of Christianity as the majority religion of the Roman Empire, and with it an indissoluble fusing of Judaeo-Christian and Romano-Greek thought. Apart from the first brief period of the founding of the religion in the time of the Early Roman Empire, there was to be no time in the whole subsequent history of the Christian Church so fertile in the development of its distinctive ideas and practices as the 'Patristic Age', lasting from roughly the mid-fourth century to the early sixth. 
The writings of such men as Athanasius, Basil, Gregory of Nazianzus, Gregory of Nyssa, Ambrose, Jerome, Augustine and their immediate successors provided the intellectual framework of Christian thinking not only throughout the rest of the Middle Ages, but also for the Reformation and more recent centuries. The distinctive Christian emphasis on Virginity and the extraordinary ideological and institutional structures of monasticism were likewise the products of these centuries. They also saw the challenge to and modification of the Romano-Christian tradition with the rise to dominance of Islam over the whole of the Near East and the southern Mediterranean. The direct relevance of this formative period of Islamic thought and institutions to the modern society of these regions and to various contemporary political and economic issues hardly needs underlining.

In the West the Roman Empire dissolved itself as a unitary political entity in the fifth century, but its intellectual and material cultural legacy continued to direct the fragmentary successor states that came into being in its ruin. Especially true was this of that extraordinary institution the papacy, whose own distinctive view of its nature and purpose was formed in this time, together with many of the institutional features that would enable it to play so dominant a role in Western Europe for centuries to come. As a corollary to this, the most substantial, and still unhealed, rift in Christendom, that between the Latin and Greek Churches, came into being at the very end of this period.

This itself was not uninfluenced by political changes in the West, with the emergence of the short-lived Frankish empire of the Carolingians, which in its territorial expansion both northwards and eastwards further extended the areas of influence of the intellectual culture and some of the material civilisation of Late Antiquity. These would be taken even further to the east in the succeeding centuries, when the German realm that was brought into being under the Ottonian kings and emperors, established itself as the dominant force in central Europe. At the same time a resurgent Byzantine Empire was once more extending its own influence both westwards and northwards, not least into the region that would become Russia, thus creating a long-lasting divide in the cultural traditions of Europe.

To turn once more to the perspective of the historian, it was perhaps easier for Gibbon in an age of relative tranquillity to take a broad, if hardly dispassionate, view of this sequence of events. His approach to it, though, was conditioned by a desire to criticise certain elements in the society of his own day that he found reprehensible, notably its penchant for apparently pointless wars of conquest and the continuing strength of elements of unreason, 
above all in religion. At the same time, a much more radical critique, symbolised by the French Revolution, was to lead directly to the subversion of much of the social order of Europe and, perhaps paradoxically, to the proliferation of aggressive warfare on an almost unprecedented scale, together with the emergence of ideologies far more menacing to Liberal individualism and reason than the placid religiosity of the eighteenth century. Flamboyant despots of the succeeding period, from Napoleon to Hitler, also turned to the Roman imperial past and its attempted revival under Charlemagne for some of the imagery and the framework of ideas needed to shape and manifest their regimes.

The revival of scholarly interest in the periods of Late Antiquity and the Early Middle Ages can, as much as the historiography of any period, partake of the quality of mere antiquarianism. However, the nature of its subject matter, the scale and significance of so many of its events, and the intellectual force of the thought of so many of its greatest writers should militate against this. History should not necessarily be expected to teach lessons, and certainly is not cyclical, but the study of these apparently remote centuries is as conducive as any to the questioning of received value systems, the evaluation of dogma and the formulation of principles to guide the conduct of states and individuals in complex times. 
For Judith 